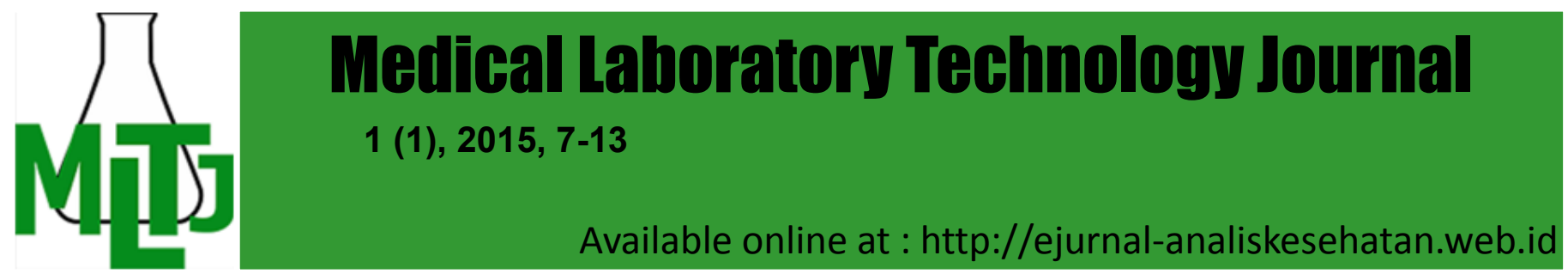

\title{
HUBUNGAN DOSIS TEPUNG GEMBILI (Dioscorea esculenta) DENGAN TINGKAT EKSPRESI ENZIM Ampk- $\alpha 2$ PADA MODEL TIKUS DIABETES MELITUS
}

\author{
Neni Oktiyani ${ }^{1}$, Sunarti $^{2}$, Prasetyastuti $^{2}$, Jujuk Anton Cahyono ${ }^{1}$ \\ 1Jurusan Analis Kesehatan Poltekkes Kemenkes Banjarmasin \\ Jl. Mistar Tjokrokusumo No. 4A Banjarbaru \\ ${ }^{2}$ Bagian Biokimia FK UGM jl Sekip Utara Yogyakarta \\ e-mail: neni.ok76@gmail.com
}

\begin{abstract}
Alternative methods of controlling glucose levels in patients with diabetes is by type of food, either by utilizing yam flour. At the flour contained inulin and resistant starch that can activate the enzyme AMPK- $\alpha 2$. Activation of these enzymes will stimulate glucose transport in skeletal muscle and liver, thus causing a decrease in glucose production. Varying doses of flour is expected to affect the expression of AMPK- 22 . This study aims to dosage relationship yam flour (Dioscorea esculenta) with tigkat- $\alpha 2$ AMPK enzyme expression in the nucleus skeletal muscle and liver in mouse models of diabetes mellitus. The study was a quasi-experimental design with Post Test Only Group Design. Rats were divided into 5 (five) groups, healthy mice, the mice with type 2 diabetes, and type 2 groups of diabetic rats with dietary intake yam flour addition of $1.25 \mathrm{~g}$ (TG-1:25),), $2.5 \mathrm{~g}$ (TG -2.5), $5.0 \mathrm{~g}$ (TG-5.0). Yam flour is mixed into the rat diet feed with varying doses. The results showed no significant correlation between the dose of yam flour with AMPK$\alpha 2$ expression levels in skeletal muscle nuclei $(p=0.312)$ and liver $(p=0.474)$ in a mouse model of DM. The need for other studies using other types of food as an alternative arrangement of food for patients with diabetes
\end{abstract}

Keywords: diabetes mellitus type 2, AMPK- $\alpha 2$, yam flour

\begin{abstract}
Abstrak: Metode alternatif pengendalian kadar glukosa pada penderita DM adalah dengan pengaturan jenis makanan, salah satunya dengan memanfaatkan tepung gembili. Pada tepung terdapat inulin dan pati resisten yang dapat mengaktivasi enzim Ampk- $\alpha 2$. Aktivasi enzim ini akan menstimulasi transpor glukosa di otot skelet dan hepar, sehingga menyebabkan terjadinya penurunan produksi glukosa. Dosis bervariasi dari tepung diharapkan mampu berpengaruh terhadap ekspresi Ampk- $\alpha 2$. Penelitian ini bertujuan untuk hubungan dosis tepung gembili (Dioscorea esculenta) dengan tigkat ekspresi enzim Ampk- $\alpha 2$ di nukleus otot skelet dan hepar pada model tikus Diabetes Melitus. Penelitian yang dilakukan adalah eksperimental kuasi dengan rancangan Post Test Only Group Design. Tikus dibagi ke dalam 5 (lima) kelompok, yaitu kelompok tikus sehat, tikus DM tipe 2, dan kelompok tikus DM tipe 2 dengan asupan makanan penambahan tepung gembili 1,25 g (TG-1.25), ), 2,5 g (TG-2.5), 5,0 g (TG-5.0). Tepung gembili dicampurkan ke dalam pakan diet tikus dengan dosis yang bervariasi. Hasil penelitian menunjukkan tidak ada korelasi bermakna antara dosis tepung gembili dengan tingkat ekspresi Ampk- $\alpha 2$ di nukleus otot skelet $(p=0,312)$ dan hepar $(p=0,474)$ pada model tikus DM. Perlu adanya penelitian lain menggunakan jenis makanan lain sebagai alternatif pengaturan makanan bagi penderita DM.
\end{abstract}

Kata kunci : diabetes melitus tipe 2, Ampk- $\alpha 2$, tepung gembili 


\section{PENDAHULUAN}

Menurut American Diabetic Association (2006), prevalensi DM di seluruh dunia adalah sekitar 4\%. Prevalensinya akan terus meningkat dan diperkirakan pada tahun 2025 akan mencapai 5,4\%. Wild et al. (2004) mengemukakan bahwa pada tahun 2000 Indonesia menempati urutan ke-4 terbesar dalam jumlah penderita DM di dunia $(8,4$ juta penderita) dan pada tahun 2030 diperkirakan 21,3 juta penderita DM.

Resistensi insulin merupakan kondisi umum yang dialami oleh penderita DM tipe 2 yang mengakibatkan penurunan fungsi mitokondria dalam metabolisme energi. Gangguan pada metabolisme energi memiliki peranan yang penting dalam menyebabkan komplikasi pada diabetes melitus akibat resistensi insulin (Segre et al., 2010).

Resistensi insulin di beberapa jaringan erat kaitannya dengan penurunan ekspresi dan atau aktivitas enzim adenosine monophosphate-activated protein kinase (AMPK) (Hojlund et al., 2004). Adenosine monophosphateactivated protein kinase (AMPK) adalah suatu serine/threonin protein kinase yang bekerja sebagai sensor keadaan energi seluler (Salminen et al., 2011). Enzim ini berperan dalam mengontrol keseimbangan energi seluler, mengontrol homeostasis glukosa, metabolisme karbohidrat dan lipid (Viollet dan Andreelli, 2011) di berbagai organ terutama otot skelet dan hepar (Gruzman, et al., 2009), regulasi biogenesis dan fungsi mitokondria, autofagi, polaritas sel dan pertumbuhan dan proliferasi sel. Adenosine monophosphateactivated protein kinase (AMPK) berperan penting sebagai regulator dalam metabolisme energi karena perannya dalam aktivasi beberapa faktor transkripsi lain seperti peroxisome proliferator-activated receptor (PPAR)- $y$ coactivator (PGC)-1a (Hardie, 2011a).
Penelitian Gao et al. (2009) menunjukkan bahwa gangguan fungsi mitokondria pada mencit dapat dicegah dengan pemberian sodium butirat. Butirat merupakan produk metabolit sekunder hasil fermentasi karbohidrat tidak tercerna oleh flora usus khususnya pati resisten dan makanan yang mengandung serat (Berni Canani et al., 2011). Pati resisten (resistant starch) merupakan karbohidrat yang tidak dapat tercerna oleh tubuh tetapi berperan sangat penting dalam menghasilkan asam butirat (Cummings et al., 2001). Inulin merupakan serat larut air namun tidak dapat dicerna oleh enzim pencernaan. Fermentasi inulin dalam kolon dapat meningkatkan jumlah bifidobacterial dan meningkatkan produksi butirat dalam kolon (De Vuyst dan Leroy, 2011; Lattimer dan Haub, 2010).

Salah satu bahan pangan yang banyak mengandung pati resisten dan inulin adalah gembili (Dioscorea esculenta). Gembili merupakan umbi lokal yang belum dimanfaatkan secara optimal oleh masyarakat namun memiliki kadar pati resisten yang cukup tinggi yaitu sebesar 10,4 mg/g berat kering (Marsono, 1998) dan kadar inulin sebesar 14,77\% (Winarti et al., 2011). Oleh karena itu gembili kemungkinan dapat digunakan sebagai bahan makanan yang dapat meningkatkan produksi asam butirat dalam kolon dan selanjutnya akan meningkatkan ekspresi Ampka2 di nukleus otot skelet dan hepar dalam upaya pencegahan perkembangan DM tipe 2.

\section{BAHAN DAN METODE}

Jenis penelitian ini adalah ekspe -rimental kuasi dengan rancangan Post Test Only Group Design. Lokasi penelitian dilakukan di beberapa tempat yaitu : Laboratorium Pusat Antar Universitas (PAU), dan Laboratorium Biokimia Fakultas Kedokteran Universitas Gadjah Mada. 
Populasi dan sampel yang digunakan pada penelitian ini adalah tikus galur Wistar jantan berumur 2 bulan dengan berat berkisar antara \pm 200 g.

Pembuatan Tepung Gembili, yaitu gembili dikupas, dipotong setebal 1-2 $\mathrm{mm}$ dan dicuci hingga bersih. Dilakukan pengeringan pada $50^{\circ} \mathrm{C}$ selama 24 jam dan di haluskan sampai menjadi tepung (ukuran 90 mesh).

Perlakuan Hewan Coba : Tikus dikandangkan dalam kandang plastik, tiap kandang berisi 10 ekor. Tikus diadaptasi selama 1 minggu dengan pemberian diet standar semipurified diets for rats sebanyak $15 \mathrm{~g}$. Selanjutnya dilakukan pembagian kelompok hewan coba menjadi 5 kelompok : kelompok I (Kelompok tikus tanpa induksi dan perlakuan pakan stan-dar), Kelompok II (Kelompok tikus induk-si DM dan perlakuan pakan standar), Kelompok III (Kelompok tikus dengan induksi DM dan pakan diet 1,25 g gembili/15 g pakan standar), Kelompok IV (Kelompok tikus dengan induksi DM dan pakan diet 2,50 g gembili/15 $\mathrm{g}$ pakan standar) dan Kelompok $\mathrm{V}$ (Kelompok tikus dengan induksi DM dan pakan diet $5 \mathrm{~g}$ gembili/15 g pakan standar).

Induksi tikus menjadi DM : Tikus dipuasakan selama 1 malam sebe-lum penginduksian pagi harinya. Induksi DM tipe 2 dilakukan dengan injeksi intraperitoneal nicotinamide (NA) $230 \mathrm{mg} /$ $\mathrm{kg}$ BB yang dilarutkan dalam larutan salin $(\mathrm{NaCl}$ 0,9\%). Setelah 15 menit, kemudian dilanjutkan dengan pemberian streptozotocin (STZ) $65 \mathrm{mg} / \mathrm{kg} \mathrm{BB}$ yang dilarutkan dalam bufer sitrat $0,1 \mathrm{M}$ dengan $\mathrm{pH}$ 4,5 secara intraperitoneal untuk merusak sel $\beta$-pankreas. Tikus dikatakan DM tipe 2 apabila kadar glukosa darahnya mengalami kenaikan $>120 \mathrm{mg} / \mathrm{dL}$ setelah induksi 5 hari.

Analisis ekspresi Ampk a-2 di nukleus otot skelet dan hepar dengan metode IHC : Proses persiapan jaringan, meliputi : fiksasi jaringan otot skelet (vastus lateralis) dalam larutan bufer formalin 10\%, Dehidrasi dengan alkohol persentase yang berbeda, Pembersihan (clearing) alkohol dengan larutan xylol. Selanjutnya dilakukan infiltrasi parafin, pencetakan/pengeblokan (embedding) dan Pemotongan dengan mikrotom.Kemudian di inkubasi pada suhu $39^{\circ} \mathrm{C}$ selama 1 malam.

Pemeriksaan imuno histokimia, meliputi : deparafinisasi menggunakan xylol, Blocking peroxidase, Antigen Retrieval, Blocking non spesific binding, IHC staining dan pengamatan dibawah mikroskop. Persentase nukleus yang mengekspresikan Ampk- $\alpha 2$ secara subjektif dinilai dari 7 lapangan pandang tiap irisan.

\section{HASIL DAN PEMBAHASAN Asupan Pakan}

Data asupan tepung gembili pada

\begin{tabular}{|c|c|c|c|}
\hline $\begin{array}{c}\text { Kelom- } \\
\text { pok }\end{array}$ & $\begin{array}{c}\text { Kandun- } \\
\text { gan gem- } \\
\text { bili dalam } \\
\text { pakan }\end{array}$ & $\begin{array}{c}\text { Rerata } \\
\text { asupan } \\
\text { pakan } \\
(\mathrm{g})\end{array}$ & $\begin{array}{c}\text { Asupan } \\
\text { tepung } \\
\text { gembili } \\
(\mathrm{g})\end{array}$ \\
\hline $\begin{array}{c}\text { K1.Seh } \\
\text { at }\end{array}$ & $0 \%$ & 12,52 & 0 \\
\hline K2.DM & $0 \%$ & 12,90 & 0 \\
\hline $\begin{array}{c}\text { TG- } \\
1.25\end{array}$ & $8,33 \%$ & 12,64 & 1,05 \\
\hline TG-2.5 & $16,67 \%$ & 12,00 & 2,00 \\
\hline TG-5.0 & $33,33 \%$ & 12,04 & 4,01 \\
\hline
\end{tabular}

tikus dapat dilihat pada Tabel 1.

Tabel 1. Asupan Tepung Gembili Pada Tikus

Keterangan :

K1.Sehat $=$ Kelompok tikus tanpa induksi dan perlakuan pakan standar $\mathrm{K} 2 . \mathrm{DM}=$ Kelompok tikus induksi DM dan perlakuan pakan standar

TG-1.25 = Kelompok tikus dengan induksi dan pakan diet $1,25 \mathrm{~g}$ gembili TG-2.5 = Kelompok tikus dengan induksi dan pakan diet 2,50 g gembili TG-5.0 = Kelompok tikus dengan induksi dan pakan diet $5,00 \mathrm{~g}$ gembili 1 
Ekspresi Ampk- $\alpha 2$ di nukleus otot skelet dan hepar

Gambaran ekspresi Ampk- $\alpha 2$ di nukleus hepar dapat dilihat pada Gambar 1.

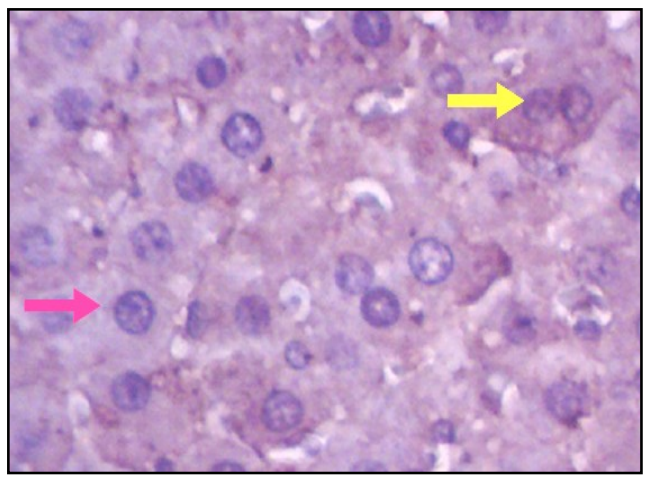

Gambar 1. Ekspresi Ampk-a2 di hepar.

Nukleus yang mengekspresikan Ampka2 berwarna coklat (ditandai dengan anak panah kuning). Nukleus yang tidak mengekspresikan Ampk- $\alpha 2$ berwarna biru (ditandai dengan anak panah merah). Pembesaran 400x.

Korelasi dosis tepung gembili dengan tingkat ekspresi Ampk-a2 di nukleus otot skelet dan hepar

Korelasi antara dosis tepung gembili dengan tingkat ekspresi Ampka2 di nukleus otot skelet dan hepar dilakukan dengan menggunakan uji korelasi Pearson. Uji hipotesis berdasarkan kekuatan korelasi (r), nilai signifikansi (p), dan arah korelasi. Hasil korelasi dosis tepung gembili dengan tingkat ekspresi Ampk - $\alpha 2$ di nukleus otot skelet dan hepar dapat dilihat pada Tabel 2 dan Tabel 3.

Tabel 2.Korelasi dosis tepung gembili dengan tingkat ekspresi Ampka2 di nukleus otot skelet

\begin{tabular}{|c|c|c|}
\hline & & Tingkat ekspresi Ampk- $\alpha 2$ \\
\hline Dosis & $\mathrm{r}$ & $-0,211$ \\
tepung & $p$ & 0,312 \\
gembili & $\mathrm{n}$ & 25 \\
& & \\
\hline
\end{tabular}

Uji Korelasi Pearson. Nilai signifikansi $p<0,05$.
Tabel 2. menunjukkan nilai signifikansi $p>0,05$ yang berarti tidak terdapat korelasi yang bermakna antara dosis tepung gembili dengan tingkat ekspresi Ampk- $\alpha 2$ di nukleus otot skelet. Nilai korelasi Pearson sebesar 0,211 menunjukkan korelasi negatif dengan kekuatan korelasi yang lemah.

Tabel 3. Korelasi dosis tepung gembili dengan tingkat ekspresi Ampka2 di nukleus hepar

\begin{tabular}{|c|c|c|}
\hline & & Tingkat ekspresi Ampk-a2 \\
\hline Dosis & $\mathrm{r}$ & $-0,150$ \\
tepung & $p$ & 0,474 \\
gembili & $\mathrm{n}$ & 25 \\
\hline
\end{tabular}

Uji Korelasi Pearson. Nilai signifikansi $p<0,05$.

Berdasarkan Tabel 3. diperoleh nilai signifikansi $p>0,05$ yang menunjukkan tidak terdapat korelasi yang bermakna antara dosis tepung gembili dengan tingkat ekspresi Ampk- $\alpha 2$ di nukleus hepar. Nilai korelasi Pearson sebesar -0,150 menunjukkan korelasi negatif dengan kekuatan korelasi yang sangat lemah.

Hasil analisa menunjukkan bahwa terdapat perbedaan bermakna asupan pakan pada minggu ke-1 dan minggu ke-3. Hal ini kemungkinan berkaitan dengan faktor intern dari masingmasing tikus. Jika dilihat dari rerata asupan pakan secara keseluruhan selama empat minggu perlakuan, tidak terlihat adanya perbedaan yang signifikan pada masing-masing kelompok. Ini berarti bahwa perbedaan perlakuan tidak mempengaruhi nafsu makan tikus sehingga rata-rata asupan pakan antar kelompok selama penelitian sama.

Pemberian pakan standar dan pakan diet sebanyak $15 \mathrm{~g}$ pada hewan coba setiap harinya dilakukan secara ad libitum (sekenyangnya). Kelemahan dari cara ini adalah bahwa tidak semua pakan yang diberikan dimakan habis oleh hewan coba sehingga perlu 
dilakukan perhitungan dosis tepung gembili dalam pakan yang dimakan.

Dosis tepung gembili yang diberikan pada masing-masing kelompok perlakuan adalah $\mathrm{K} 1$.Sehat $0 \mathrm{~g}$; K2.DM 0 g; TG-1.25 1,25 g; TG-2.5 2,5 $\mathrm{g}$ dan TG-5.0 5,0 g. Hasil perhitungan jumlah tepung gembili dalam pakan yang dimakan hewan coba pada kelompok K1.Sehat $0 \mathrm{~g}$; K2.DM $0 \mathrm{~g}$; TG-1.25 1,05 g; TG-2.5 2,00 g dan TG-5.0 4,01 g. Jika dikonversi asupan tepung gembili tikus ke manusia dengan faktor konversi 0,018 dan nilai rendemen gembili menjadi tepung gembili sebesar $16,21 \%$, maka didapatkan jumlah asupan tepung gembili tikus setara dengan K1.Sehat $0 \mathrm{~g}$; K2.DM $0 \mathrm{~g}$; TG-1.25 $359,84 \mathrm{~g}$; TG-2.5 685,44 g dan TG-5.0 $1374,34 \mathrm{~g}$ gembili pada manusia.

Penelitian Gao et al. (2009) menyebutkan bahwa butirat dapat menurunkan glukosa darah puasa sebesar $30 \%$ dan resistensi insulin sebesar $50 \%$. Mekanismenya terkait dengan peningkatan energy expenditure dan induksi fungsi mitokondria melalui aktivasi adenosine monophosphateactivated protein kinase (AMPK). Enzim Ampk- $\alpha 2$ memiliki peran penting dalam penggunaan glukosa oleh otot melalui translokasi glucose transporter-4 (GLUT-4) dan meningkatkan metabolisme glukosa dengan meningkatkan biogenesis mitokondria (Fujii et al., 2005). Selain itu meningkatkan oksidasi asam lemak dan menurunkan produksi glukosa, kolesterol dan trigliserida di hepar. Efek metabolik ini terkait dengan penurunan kadar glukosa plasma (Gruzman et al., 2009; Hardie, 2011b). Adenosine monophosphateactivated protein kinase (AMPK) berperan penting sebagai regulator dalam metabolisme energi karena perannya dalam aktivasi beberapa faktor transkripsi lain seperti peroxisome proliferator-activated receptor (PPAR)- $y$ coactivator (PGC)-1a (Hardie, 2011a). Faktor transkripsi ini merupakan koaktivator transkripsi yang mengontrol berbagai faktor transkripsi lainnya seperti estrogen-related receptor (ERR)- $\alpha$, nuclear respiratory factor (NRF)-1 dan 2, peroxisome proliferator-activated receptor (PPAR)- $\alpha$ dan $\mathrm{y}$ dan thyroid hormone receptor yang berperan langsung dalam biogenesis mitokondria, metabolisme glukosa dan asam lemak serta pernafasan (Gao et al., 2009).

Enzim AMPK memiliki 3 subunit $(\alpha, \beta, y)$. Isoform 2 subunit alpha (Ampk - $\alpha 2$ ) banyak diekspresikan pada jaringan otot skelet dan hepar yang memiliki peran penting dalam penggunaan glukosa oleh otot melalui translokasi glucose transporter-4 (GLUT-4) ke membran plasma dan meningkatkan metabolisme glukosa dengan meningkatkan biogenesis mitokondria (Fujii et al., 2005). Enzim ini dapat meningkatkan sensitivitas insulin dengan meningkatkan oksidasi asam lemak dan mengurangi penyimpanan trigliserida karena jumlah trigliserida otot yang berlebihan dikaitkan dengan resistensi insulin (Hardie, 2011b). Selain itu, enzim ini dapat mencegah biosintesis kolesterol dan trigliserida dan mencegah glukoneogenesis di hepar (Gruzman et al., 2009; Hardie, 2011b).

Berdasarkan hasil uji korelasi Pearson didapatkan hasil yang menunjukkan bahwa terdapat korelasi yang tidak bermakna antara dosis tepung gembili dengan tingkat ekspresi Ampka2 di nukleus otot skelet dan hepar. Nilai korelasi Pearson negatif artinya korelasi bersifat berlawanan arah, semakin besar nilai satu variabel maka semakin kecil nilai variabel lainnya. Hasil penelitian menunjukkan bahwa semakin besar dosis tepung gembili semakin rendah tingkat ekspresi Ampk- $\alpha 2$ di nukleus otot skelet dan hepar.

Tingkat ekspresi Ampk- $\alpha 2$ paling tinggi justru terjadi pada kelompok TG-1.25 dengan dosis tepung gembili paling kecil yaitu 1,05 g. Sedangkan kelompok TG-2.5 dan TG-5.0 dengan 
dosis tepung gembili lebih besar menunjukkan tingkat ekspresi Ampk- $\alpha 2$ yang lebih rendah dibanding kelompok TG-1.25. Hal ini terjadi karena pada kelompok TG-2.5 dan TG-5.0 kandungan serat dan $\mathrm{RS}$ lebih tinggi dibanding kelompok TG-1.25. Fermentasi serat dan RS berlebih di kolon akan menghasilkan energi, untuk serat sebesar 1,5 $\mathrm{Kkal} / \mathrm{g}$ (Tensiska, 2008) dan RS sebesar $2 \mathrm{Kkal} / \mathrm{g}$ (Nugent, 2005). Selain itu kandungan karbohidrat pada kelompok TG-5.0 sangat tinggi. Berdasarkan perhitungan pemenuhan gizi karbohidrat pada kelompok TG-5.0, didapatkan hasil kandungan karbohidrat dalam tepung gembili sebesar $132,45 \%$. Kelebihan energi menyebabkan aktivasi Ampk- $\alpha 2$ menurun.

\section{KESIMPULAN}

Dari hasil penelitian disimpulkan bahwa tidak ada korelasi bermakna antara dosis tepung gembili dengan tingkat ekspresi Ampk- $\alpha 2$ di nukleus otot skelet $(p=0,312)$ dan hepar $(p=$ $0,474)$ pada model tikus DM tipe 2.

\section{SARAN}

Disarankan perlu kajian bahan pangan lokal lain terhadap ekspresi Ampk- $\alpha 2$ dan perlu dilakukan penelitian ekspresi Ampk- $\alpha 2$ di jaringan-jaringan lain.

\section{UCAPAN TERIMAKASIH}

Penelitian ini merupakan bagian dari Tesis, sehingga disampaikan ucapan terimakasih kepada Institusi Poltekkes Kemenkes Banjarmasin yang telah membiayai.

\section{DAFTAR PUSTAKA}

American Diabetes Association, (2006). Diagnosa and classification of diabetes mellitus. Diabetes Care. 29(1 Suppl): 43S - 48S.

Berni Canani, R., Di Costanzo, M.,
Leone, L., Pedata, M., Meli, R., Calignano, A. (2011). Potential beneficial effects of butyrate in intestinal and extraintestinal diseases. World J. Gastroenterol. 17(12):1519-1528.

Cummings, J.H., Macfarlane, G.T., Englyst, H.N. (2001). Prebiotic digestion and fermentation. Am. J. Clin. Nutr. 73(1supp):415S$420 S$.

De Vuyst, L., Leroy, F. (2011). Crossfeeding between bifidobacteria and butyrate-producing colon bacteria explains bifdobacterial competitiveness, butyrate production, and gas production. Int. J. Food Microbiol. 149:73-80.

Gao, Z., Yin, J., Ward, R.E., Martin, R.J., Lefevre, M., Cefalu, W.T., Ye, J. (2009). Butyrate improves insulin sensitivity and increases energy expenditure in mice. Diabetes. 58:1509-1517.

Gruzman, A., Babai, G., Sasson, S. (2009). Adenosine Monophosphate -Activated Protein Kinase (AMPK) as a New Target for Antidiabetic Drugs: A Review on Metabolic, Pharmacological and Chemical Considerations. Rev. Diabetic Studies. 6 (1): 13-36.

Hardie, D.G. (2011a). AMP-activated protein kinase - an energy sensor that regulates all aspects of cell function. Genes Dev. 25(18):1895 $-1908$.

Hardie, D.G. (2011b). Sensing of energy and nutrients by AMPactivated protein kinase. Am. J. Clin. Nutr. 93(suppl):891S-896S.

Hojlund, K., Mustard, K.J., Staehr, P., Hardie D.G., Nielsen, H.B., Richter, E.A., Wojtaszewski, J.F.P. (2004). AMPK activity and isoform protein expression are similiar in muscle of obese subject with and without type 2 diabetes. Am. J. 
Physiol. Endocrinol. Metab. 286:E239-E244.

Marsono, Y., (1998). Perubahan kadar resistant starch (RS) dan komposisi kimia beberapa bahan pangan kaya karbohidrat dalam pengolahan. Agritech. 19(3):124127.

Nugent, A.P. (2005). Health Properties of Resistant Starch. British Nutrition Foundation. 27-54.

Salminen, A., Hyttinen, J.M.T., Kaarniranta, K. (2011). AMP- activated protein kinase inhibits NF$\mathrm{k} \beta$ signaling and inflammation: impact on healthspan and lifespan. J. Mol. Med. 89:667-676.

Segre, A.V., DIAGRAM Consortium, MAGIC Investigators, Groop, L., Mootha, V.K., Daly, M.J., Altshuler, D. (2010). Common In- herited Variation in Mitochondrial Genes Is Not Enriched for Associations with Type 2 Diabetes or Related Glycemic Traits. Plos Genet. 6(8): $\quad$ e1001058. doi:10.1371/ journal.pgen.1001058.

Tensiska. (2008). Serat Makanan. Jurusan Teknologi Industri Pangan Fakultas Teknologi Industri Pertanian Universitas Padjadjaran.

Viollet, B., Andreelli, F. (2011). AMPactivated protein kinase and metabolic control. Handb. Exp. Pharmacol. 203:303-330.

Wild, S., Roglic, G., Green, A., Sicree, R., King, H. (2004). Global Prevalence of Diabetes: Estimate for the year 2000 and projections for 2030. Diabetes Care. 27:1047 -1053 . 